\title{
6. Friends and Strangers:
}

\section{A Conversation}

\section{REX BUTLER}

CATHERINE WHEATLEY

"I write for friends and strangers." So writes Stanley Cavell in Little Did I Know, misquoting Gertrude Stein (who in fact wrote for herself and for strangers). ${ }^{1}$ Cavell long wrestled with uncertainty about how his books would be-and had been-received, with whether he could make himself understood to his readers. The friends who share his conviction that everything-art, language, autobiography-matters, and that we must try as best we can to communicate with others. The strangers whose minds are more mysterious still, but to whom he felt a duty to reach out. On the occasion of the publication of our respective books, Stanley Cavell and Film: Scepticism and SelfReliance at the Cinema (Bloomsbury, 2019) and Stanley Cavell and The Arts: Philosophy and Popular Culture (Bloomsbury, 2020), we read one another's work and were moved to begin a conversation. Here, we speak to each another about finding Cavell, the tricky business of interpretation and the future of Cavell studies.

REX BUTLER (RB): I've just finished reading your book Stanley Cavell and Film: Scepticism and Self-Reliance at the Cinema (2019) for the third time and was struck once again by how clear and measured it is. There are lots of similarities between our approaches to Cavell, but unfortunately your book arrived too late for me to make much use of it in what I have written. Probably no one will believe that! But I guess I'd like to begin by asking when and how you first came across Cavell's work. There are, of course, quite a number of important British interpreters of Cavell. Was his work in the atmosphere when you started your $\mathrm{PhD}$, for example?

1. Cavell, Little Did I Know: Excerpts from Memory (Palo Alto, CA: Stanford University Press, 2010), 444. 
CATHERINE WHEATLEY (CW): Thank you for your kind words, and for sharing your book with me-sadly too late for me to respond to it in what I wrote either! Perhaps this conversation is a way of making up for that missed opportunity on both our parts.

In answer to your question I first came across Cavell around 2004 while I was writing a PhD thesis on the films of Michael Haneke and the ethics of film spectatorship (which was the basis for my 2009 monograph Michael Haneke's Cinema: The Ethic of the Image, 2009). I was casting around for philosophical approaches to film and came across Pursuits of Happiness and Contesting Tears, and from there I found The World Viewed and The Claim of Reason. I can't say I was immediately captivated by all of Cavell's film-related work-I'd been thoroughly trained in a close-analysis approach to film that was very oriented to the technical language of cinema-thinking about editing, camera movements, the details of mise-en-scène, and of course Cavell completely rejects that way of talking about film. So, while I found there was something really wonderful in his version of perfectionism that really helped me unlock Haneke's films and my responses to them, at the time I wasn't quite convinced by his method of criticism. In fact I think I wrote in that book words to the effect that Cavell was largely uninterested in film form, which Lisa Trahair rightly took me to task for in an article she published on automatism and Cavell. ${ }^{2}$

It was really only after I'd finished my PhD that I came to a deeper appreciation of his work. In 2006 I read Cities of Words and Philosophy the Day After Tomorrow, and also attended a conference at Cambridge, in the Faculty of English, called “Acknowledging Cavell: His Multidisciplinary Legacy,” where I was lucky to hear papers by Alice Crary and Stephen Mulhall and to make the acquaintance of Andrew Klevan, who along with Stephen has been one of Cavell's most incisive commentators in the UK. Interestingly, 2006 was not only the year of Cavell's eightieth birthday, but also the year that the Film-Philosophy journal and conference was founded. That journal has gone on to really shape the field and the conference has been a terrific pathway for me to meet other scholars interested in the conjunction of philosophy and film and in Cavell as a kind of founding father of that endeavour.

2. Lisa Trahair, "Serious Film: Cavell, Automatism and Michael Haneke's Caché," Screening the Past 38 (2013), http://www.screeningthepast.com/issue-38-cinematic-thinking/serious-film-cavell-automatism-and-michael-haneke's-cache. 
RB: Well I suppose following on from that I'd want to ask what first drew you to his work. There are moments-we'll come to that in a moment-where as a feminist you obviously take a certain distance onto him. Did you immediately like what he was saying or was he something of an acquired taste? Did he in any way stand against what you felt to be the dominant sensibility of your peers? Or even the way you were thinking at the time?

CW: I certainly don't think Cavell was very fashionable at the time I first encountered him. Certainly not in the way that, say, Judith Butler, Slavoj Žižek or Gilles Deleuze were. Or indeed Emmanuel Levinas, whose ethical philosophy has brought been into relationship with film in very rich, productive ways by scholars such as Sarah Cooper, who edited a special issue of Film-Philosophy on Levinas and Film in 2008. (It wasn't until 2014 that Robert Sinnerbrink edited a similarly themed issue on Cavell and Film). But also I had the feeling that the scholars who had engaged with Cavell-former students such as William Rothman and Sandra Laugier, or those who were early to respond to his work, like Andrew and Stephen and Robert-had done so in such a rich, thorough-going manner that it was hard to not be overwhelmed by their work. I found it a real balancing act, writing the book, to interweave their lucid appraisals of Cavell with my own responses to his work.

$\mathrm{RB}$ : One of the more extended aspects of your analysis is the question of woman in Cavell's work. You comment on what Cavell understands as the dissymmetry between the sexes in the comedies of remarriage and you take up the much-discussed matter of Cavell's thinking of the place of woman in the female melodramas. In particular, you conclude your analysis of King Vidor's Stella Dallas (1937) by following Robert Sinnerbrink's suggestion that Stella's actions at the end of the film when she leaves her daughter and walks offscreen are to be understood neither as the film's erasure of Stella nor as a self-conscious decision by Stella herself. You precede this by taking us through the long history of feminist objection to Cavell's reading of the melodramas in general, to which you are broadly sympathetic. A hard question, but how would you try to summarise how you stand with regard to Cavell's relationship to the femi- 
nine (and feminism), and how do you see this playing out in his reading of say Stella Dallas?

Similarly-and I had not really put my mind to this before I read your bookyou raise the question of race in relation to Cavell's reading of the famous shoeshine scene in Vincente Minnelli's The Band Wagon (1953), in which Fred Astaire dances with a black shoeshine man in an amusement arcade. Here too Cavell's reading of the sequence has been criticised by some and defended by others. How do you think Cavell's interpretation of it in Philosophy the Day after Tomorrow stands up today in contemporary America?

CW: Those are tricky questions!

To begin with matters of gender, female experience is central to much-if not all-of Cavell's work on film, not least because he believes film to show a far greater interest in its female subjects than it does in its male subjects. Film is, "about the creation of woman, about her demand for an education, for a voice in her history."3 And yet, at the same time, such perspicuous critics such as Tania Modleski have claimed that in Cavell's film-philosophy women's voices are ultimately silenced. My own sense is that Cavell tries-not always successfully, it should be said-to heed female voices, and to pay attention to the ways in which they are silenced, and in which they speak. This is a theme in his writing on Shakespeare as much as it is on films such as The Awful Truth and Stella Dallas. In his essay on the latter, in particular, Cavell clearly struggles to appropriately respond to the woman's voice while at the same time attempting "not to explain the woman's thinking, to enable us to know what she knows; [...] to listen to her voice in order to enable a sort of understanding-an understanding beyond explanation-to take place."4 Surely this is good advice for us all: that we try not only to speak better, but also to listen better?

This leads me on to the second part of your question. I have absolute sympathy with Cavell's passionate defence of what he calls Astaire's dance of praise in his essay on The Band Wagon. And at the same time I find Robert Gooding-Williams' critique

3. Cavell, A Pitch of Philosophy: Autobiographical Exercises (Cambridge, MA: Harvard University Press, 1994), 134.

4. Cavell, Contesting Tears: The Hollywood Melodrama of the Unknown Woman (Chicago, IL: University of Chicago Press, 1996), 234. 
of it as perpetuating institutional racism very persuasive. The question what constitutes an ally is a very difficult one, and not necessarily one that I feel best qualified to speak on, but it is important that we continue to pose that question, even if we risk exposing ourselves to criticism. We learn, after all, through failure. Naomi Scheman's beautiful essay "A Storied Life" seems to me to express beautifully the ambivalence I feel about some of Cavell's claims to speak for others, both in terms of gender and race. 5 There she concludes that it is an open and vexed and question whether any one of us can speak for all of us: whether there is, in any interesting sense, an unbounded, human we at all. Many would answer no, and go on to say that, perhaps for that reason, there cannot and should not be philosophy at all-or at least not in the way we have known it. And yet giving up on the possibility of general claims is the final roost of privilege. Whether any of us can, in good conscience, enter a claim on another's behalf depends of course on a complex initiation of acknowledgement and recognition. But the ethics of the I / you is, ultimately, not an acceptable replacement for the political address of the we.

With that in mind, I think Cavell's philosophy, and his film-philosophy in particular, might have great value for critical race theory. Acknowledgement, for example, has become an absolutely key political term in the current moment, not least in discourse centred around film. Take Joaquin Phoenix's BAFTA speech-in which he famously calls out systemic racism. He says there: "I don't think anybody wants a handout or preferential treatment. People just want to be acknowledged and appreciated and respected for their work." Likewise I recently watched a very moving video of what's called a "privilege walk." The idea is that a group of diverse individuals stand in a line, and each take one step forward every time they have benefitted from social norms, and one step back every time they've been disadvantaged or discriminated against: there are a few of them online and they are a sobering watch. At the end of this particular one the person left furthest back-an Indigenous Australian mantells the others that "it's not a competition of who has it the worst, or the best or the most or the least-it's about acknowledging it, it's about recognising it.”

5. Naomi Scheman, “A Storied World: On Meeting and Being Met," in Stanley Cavell and Literary Studies: Consequences of Skepticism, ed. Richard Eldridge and Bernie Rhie (New York: Continuum, 2011), 92-105. 
This call for an acknowledgement of difference, of seeing the other for who and what they are, and for changing our behaviour in the light of that acknowledgement, is at the heart of so much of Cavell's philosophy. It shouldn't be a great leap to thinking about racial difference, sexual or gender difference in these terms. And one of the things that I find so crucial in Cavell is his emphasis on the importance of disagreement. It's ok not to see things the same way: indeed, this is how we learn from one another. Simply walking away and saying "I'm not going to persuade her, so why bother trying"-this is the ethical failure. It's crucial to Cavell that we find our voices, and attempt to make them heard, but also that we listen to other voices-that we have good pitch, as he puts it. In an era of cancel culture, no-platforming and internet communication, where it's easier than ever to retreat into political echo-chambers, acknowledgement is a lifeline.

RB: One or two more questions. Like any author, what do you wish, now that you've written the book, you'd paid more attention to? What strikes you as a potentially underdone area of Cavell's relationship to film? Or to put this another way, what are you working on now? What has writing your book opened up to you?

CW: As you've mentioned, I tried to be attentive to-and a little bit testing of-Cavell's approach to gender and race within the book, and I'm really pleased that the book comes across as pushing back a little on some of Cavell's claims. I think Cavell himself is aware of the limits of what he calls his "representativeness." In his final, autobiographical work, Little Did I Know, he worries about his ability to speak for others, making reference specifically to women. But I rather fudged the question of sexuality.

To some extent, this is because Cavell himself fudges the question of sex. Marriage is configured as a kind of special friendship, and gender is important within that, but he says so little about love and eroticism-partly because the couple have to be childlike, and partly because they have to be childless: the stakes of marriage can't have to do with the perpetuation of the patriarchal line. At one point in Cities of Words he tries to draw a more or less straightforward comparison between Platonic friendship and marriage-which seems to me surely wrong. (When he talks about the exemplar he states that they must be distinterested, in terms of their relationship to 
the one learning from them-but marriage should never be disinterested.) On the other hand, it's one of the important features of remarriage that it is precisely not a coup de foudre but something enduring-what we might called settled companionship. Is long-term love sexless? So many of the couples in the remarriage comedies are strangely chaste. You yourself say that they are able "to see the other clearly without the blinkers either of romantic love or sexual attraction." Some critics-such as Sarah Churchwell-read sex as sublimated into the dialogue, given that these are of course all works produced in the Hays Code era. But that's not Cavell's line. So I'd like to give more thought to the importance of sex and romance and love and their relationship to one another in Cavell's philosophy.

Related to this, I am interested in looking at what productive relationship Cavell might have to Queer Theory. Not particularly as regards his engagement with Sedgewick in Contesting Tears, which I fear might court similar allegations of appropriations to those that Modleski makes in regard to gender, but in terms of how same-sex couples and queer relationships more widely might complement and problematise the idea of remarriage. Cavell raises this question at a few points in his writing, but always leaves it tantalisingly hanging. Lee Wallace, of the University of Sydney, has been doing some really interesting work on this topic, and I'm excited to read her forthcoming book, Queer Remarriage. I've also been reading Maggie Nelson's The Argonauts recently, and she makes heavy reference to Wittgenstein and the ordinary and domestic in relationship to queer experience. It strikes me that she might have something interesting to say to Cavell, and vice-versa-I'd like to try to bring the two together and see what it yields.

RB: You say at one point in your book that for Cavell it is not a matter of film simply dramatising ethical or philosophical issues. This would not be what a proper film philosophy would be. You then with regard to Cavell's notion of perfectionism set out how Cavell does practice a proper cinematic ethics. Can you perhaps elaborate this a little more? And maybe tell us why Cavell's work would not therefore fall prey to the accusation that it deals only with a "small corpus of films from a single national cinema," i.e., that his notion of perfectionist ethics is culturally specific or relative? 
CW: I do that say that, although on reflection I'm not sure it's entirely the correct way of putting it. What I meant by "ethical or philosophical issues" is what Cary Grant's character, in His Girl Friday (1940), calls "that ethics stuff": front page issues about abortion or the death penalty, or theoretical propositions like the Trolley Problem. That is not what Cavell or the films that he writes about are interested in. But they are interested in questions of what it is to live a good life, to be a good person, and these are philosophical issues of a sort, too. Perhaps I might have better said that these films dramatize the philosophical question of how best to live in the world under current conditions. As Cavell puts it in his essay "Moral Reasoning" these films show us that "the moral life is not something constituted by isolated judgements of striking moral and political problems but is a life whose texture is a weave of cares and commitments in which at any time choice may present itself in pondering which you will have to decide whose view of you is most valuable to you."6

Now we might think about such questions away from film, of course. However, film's focus on the ordinary details of human life, on relationships and conversations and interactions, its particular focus on vision and visibility and what is not visible but must be discerned, poses these questions in a new and pressing manner. And while for Cavell, the Hollywood comedies and melodramas he writes about are a particularly striking, complete and let's say North American, example of how film engages with ethics, they are not the only examples. After all, Cavell also writes about Rohmer's A Winter's Tale (Conte d'hiver, 1992), Chantal Akerman's La Captive (2000), Bergman's Smiles of a Summer Night (Sommarnattens leende, 1955) in some of these terms. Just so, I think Alain Gomis's Félicité (2017), Mia HansenLøve's Things to Come (2016) or Christian Petzold's Phoenix (2014) are all films that open onto perfectionism in fascinating ways.

But more than this, film demands that its viewers practice a particular kind of responsiveness or attentiveness or care. And that attention is in itself ethical. So as a medium it is ethical-or at least the good instances of it are, in that it asks us to take it seriously and for each of us to respond on our own terms. To be faithful to our experience of the film. In the book, I discuss this in terms of Cavellian criticism, but even 
prior to this moment of writing or talking about film, there is a practice of Cavellian viewing that is inherently ethical.

RB: Finally, a bit more generally, how do you think Cavell stands today? There seems, even before his death, to have been an enormous resurgence of interest in his work. You speak very well in your book of how slow recognition was to come for Cavell's writings on film, but today he is one of the central figures of a new film-philosophy. What do you think accounts for Cavell's current reception? What felt need or lack, cultural or political, do you see his work as responding to? Do you think it is anything as simple as the end of post-modernism or the shortcomings of relativism? How do you think he speaks to an era of identity politics and the failure of progressive thought in many contemporary democracies?

CW: On the one hand Cavell has, as I say in the book, moved from the margins of philosophy, film studies, and literary studies, amongst other disciplines, to somewhere more central. I've lost count of the number of conferences and symposia on his work that have taken place in the last year, and of course ours are just two of several books coming out at the moment! On the other hand, it seems to me that a lot of the work on Cavell is still being done by the individuals whom you elegantly refer to as Cavell's supporters. And they are by and large working within in a very Cavellian tradition, both in terms of their approach to Cavell and the objects of their critique. It seems to me that Cavell hasn't been widely taken up and used in the same way that, say, Gilles Deleuze has. Where's the book on Cavell and Global Film? Or Cavell and the Digital? Of course, there are good reasons that these works haven't been produced, to do with Cavell's methodology-his work doesn't lend itself to being conceptualised and decontextualised in the same way as Deleuze's does. I think that it's possible he's hamstrung by his own attachment to ordinary language and desire to avoid prescriptiveness. Put it this way: it's an absolute joy to teach Cavell, to teach students the kind of attentiveness that he calls for, but it's very difficult to set essays on Cavell.

But as I've said above, I think that there are a number of really productive directions for Cavellian scholarship to pursue, and I absolutely think that questions of acknowledgement and care should be at the centre of our conversations in the cur- 
rent era. The French philosopher Luc Ferry makes the argument in his book On Love that until recently four great principles of meaning have dominated ethical thinking, and society as a whole: the cosmological principle, the theological principle, the humanist principle, and the principle of deconstruction. Now, he says, the dominant principle is that of love, which forms the basis for a new kind of humanism: not of reason and rights but of solidarity and sympathy. I think it's a position that's not a million miles away from Cavell. It all comes down to love again!

Now, I'd like to ask you some questions in return. I was really struck by the fact that you dedicated three chapters of your book to two of Cavell's key interlocuteurs-the film scholar William Rothman and art critic Michael Fried. Could you tell me a bit about what was behind that decision, and how you see their particular relationship to Cavell? Did you feel a similar weight of existing scholarship upon your writing?

RB: I'd admit to all kinds of interlocutors in my reading of Cavell. I suppose to begin with all of the other people I've read seriously: Baudrillard, Žižek, Deleuze... I came to Cavell through two distinct and maybe even opposed paths. On the one hand, I was intellectually formed by a period of post-modernism in Australian intellectual life, when "French theory" replaced the traditional humanities. On the other hand, as a practising art historian, I've always had a soft spot for modernism and the great modernist critics' privileging of “aesthetics.” I first encountered Cavell's work when I started teaching a film course and set readings from his books on the comedies of remarriage and melodramas of the unknown woman. I later taught advanced courses putting together Cavell, Fried and Rosalind Krauss (more on whom later). Yes, I was utterly intimidated-and maybe even a little exhausted-by the mountain of writing on Cavell. I felt that to do anything worthwhile I'd have to try to break with it as strongly as possible. Needless to say, after you finish your book in a rush of inspiration and self-belief, you can see how much of what you said has already been said by others.

$\mathrm{CW}$ : In some of your questions on race and gender, you seem to be asking me, to some extent at least, where Cavell ends and I begin. Or to what extent I feel Cavell can spe- 
ak for me. Perhaps I could pose that question to you. You write about the question of interpretation (referencing Cavell's "A Matter of Meaning It"). To what extent is what we're doing interpreting Cavell? How do you conceive of your relationship to your subject in writing a book like this?

RB: I have this very peculiar sense of what truly important thought does. It effectively "doubles" what is, proposing a new transcendental condition for things. Baudrillard puts forward simulation. Deleuze difference. Derrida différance. Cavell scepticism. Each major thinker has their own unique word for it, but the same gesture gets repeated. Of course, this is very different from the usual modest, incremental, conversational reading of Cavell as a democratic or egalitarian thinker who speaks in "ordinary language." But I think implicit in the idea of conversation for Cavell-and in Wittgenstein's language games, at least for Cavell-is this idea of doubling. Each successive statement in an authentic conversation seeks to speak the reason for the other saying what they did in an attempt to determine the conventions according to which they speak. Each in a way "re-marks" the other. And there is indeed something "comedic" in this, hence Cavell's fascination with the joke or witticism in Shakespeare, Beckett and the comedies of remarriage. So I see Cavell as a "great" thinker of enormous ambition and reach, like Nietzsche and indeed Emerson. And I have tried myself to respond to him in this spirit. The interpreter must themselves attempt somehow to "double" Cavell, which in fact for me was precisely and paradoxically to see him in this way. I nervously await Cavell scholars' response!

CW: My book is concerned with cinema-with how Cavell's cinematic education shapes his way of thinking and feeling. I mention opera and theatre and literature, but really only in so far as they relate to film. It seems to me though that, while film is at the centre of your book (literally-chapters four to six of ten in total focus on film), you also decentre it, placing it in a complex network of relations with the other arts, including theatre and photography. Do you feel that the tendency of scholarship to carve Cavell's work into subdisciplines-Literary Studies, Politics, Philosophy, Film Studies-does an injustice to his thought? To what extent is it important to take a ho- 
listic view of his work? And how does one do that with a scholar who has written so broadly and so prolifically?

Related to this, and this is a question about your own approach to art perhaps as much as it is about Cavell's, what is the internal relationship between these art forms? I was struck by how your writing on Wittgenstein and family resemblance in the chapter on modernism seemed to describe very well the way in which Cavell thinks about genre. Cavell very often maps theatre or opera onto film, or poetry on philosophy. How successful do you feel this is as an approach? I suppose I'm asking you what is the importance of medium-specificity...?

RB: Of course, really powerful thinkers cross all disciplines, including ones they've never written about, so at once it's not surprising that so many of these disciplines have taken him up and the question is posed of what the "Cavell" in common to them all is. Could all of these disciplines, which perhaps have nothing in common, actually only have Cavell in common? There's an interesting question of "family resemblance"!

And I guess in another way we can ask after Cavell what painting and film have in common. In The World Viewed, at least at first, they are opposed. As Cavell writes in the chapter "Sight and Sound" there, in cinema the spectator is automatically set back from the screen, while in painting it is the painting that must seek to set itself back from the spectator. It is something like this that Fried draws on when he writes in his famous essay "Art and Objecthood" that cinema is not a proper art because it is not involved in questions of scepticism and its overcoming. But then, as Cavell saysand you cite this in your book-our "natural relation" to movies is broken and we are not automatically set back from the screen and film has to acknowledge the spectator and seek to set them back from the screen in a way it once did automatically. 7 At this point, we might say that cinema becomes a properly modernist artform and equally, although Cavell does not explicitly spell it out, it is possible that other media can effectively function like movies, or rather that several "different" media in the old sense can be seen to be involved in the "same" problem of the spectator before a screen. Cavell himself hints at this when he speaks of the relation between film and television in 
his essay 'The Fact of Television' and Rothman too when in his recent book on Hitchcock, Must We Kill the Thing We Love? he discusses both Hitchcock's films and television series. The relationship between painting and photography is at stake in Fried's Why Photography Matters as Art as Never Before (a fascinating title, insofar as previously in "Art and Objecthood" he approved only of the "individual arts" and not "art" as such) and Krauss in the last twenty years has begun thinking what she calls a "post-medium" that explicitly admits the possibility of "hybrid" media. In a complex way-and we could say a lot more about this-what is at stake is a certain quality (not a particular medium) that connects various instances of art that can then be understood to speak to and test each other. It is this that Cavell means when he says that "the later history [of a genre] must be told with this new creation as a generating element" in Pursuits of Happiness. ${ }^{8}$ It is this quality or set of characteristics that can be shared across different physical media, producing in effect a new medium. Krauss for her part will say that in post-medium art a particular medium re-marks several different media, and I think she is right in this. Of course, in principle, as each new member is added to this modernist lineage, it is seeking to be that single quality that all of the others must possess. Each new member, as it were, points to a new quality that reconfigures the old medium, producing a different past or cross-section of examples. A new comedy of remarriage, for example, could determine that children are possible and constitute a new genre, or at least meaning to the previous genre. This is what is at stake when Cavell says in Pursuits of Happiness that a genre emerges "full-blown" and yet it is always possible to add new members to it.9 And to put all of this in terms of "family resemblance," I am reminded of Jorge Luis Borges' great essay "Kafka and His Precursors"-Borges being another of my interlocutors in my reading of Cavell when he speaks of "Kafka" being that "something in common" to a series of literary precursors that were previously seen to have "nothing in common." "Kafka" for me here would be a perfect example of a new medium in literature.

CW: You argue very persuasively in your introduction that Cavell's thought is not post-ideological, nor is it utopian, but is rather aporetic: that "scepticism and its 
other are not to be separated, but are as it were the world and its condition, which revolve around each other in a circle that constitutes the 'very time and space' of Cavell's philosophy." How do you distinguish Cavellian scepticism from other, earlier models of scepticism?

RB: Another complex and vexed question! Of course, there are a series of essays-I cite in my book Danièle Moyal-Sharrock's 'Too Cavellian a Wittgenstein: Wittgenstein's Certainty, Cavell's Scepticism',1o but there is also James Conant, David MacArthur, Davide Sparti, Elli Friedlander, etc., etc.-that discuss how and to what extent the problem of scepticism is already in Cavell's great philosophical source, Wittgenstein. That is, the question is raised as to whether the problem of scepticism is actually at stake in Wittgenstein or Cavell effectively reads it into him. Nevertheless, Cavell does see scepticism in Wittgenstein and, moreover, the decisive thing he sees in him is that he does not simply propose a solution to it or some way of living outside of it. Rather, everything we do is a response to a "prior" scepticism, and even when we feel we have overcome scepticism this is only another form of scepticism.

This is the whole problem or even contradiction of the "ordinary" in Cavell: the "ordinary" or some finality to scepticism must be striven for, but it also is unable to be named or any naming of it is only to plunge us back into scepticism. And, equally, after the hypothesis of scepticism, there is no before scepticism because this too can now only be thought as a certain overcoming of scepticism. We see this in Fried's art history, where both that previous "defeat" of theatricality he spoke of is now understood as only something of a momentary truce and he keeps on having to go back further into art history to find a moment before the advent of theatricality because he could no sooner name any such moment than it would become theatrical. If the medium is always in a sense post-medium, so the pre-medium is already medium. And something like this is at stake in Cavell's relation to the history of philosophy. Of course, in a way the entire history of philosophy can be seen as the successive attempts to overcome scepticism-Descartes, Kant, Hume...-but only after Cavell. The power of a pure doubling transcendental statement-which is something of a pres-

10 Danièle Moyal-Sharrock, “Too Cavellian a Wittgenstein: Wittgenstein's Certainty, Cavell's Scepticism', in Understanding Wittgenstein, Understanding Modernism, ed. Anat Mater (London: Bloomsbury, 2017), pp. 92-110. 
criptive or performative-is that, after it, what it speaks of appears as though always there.

CW: Questions of post-modernity and modernity, or post-modernism and modernism are at the heart of your book. What do you see the role of history as being? Can we ever abstract Cavell's philosophy from its historical context? And from here - where do you see it leading us? What is the future for Cavell, and of Cavell? You write elegantly about how we are to read Cavell today, but if we can't-as you rightly argueabstract certain concepts like remarriage from their historical settings, then how do we do things with Stanley Cavell?

RB: To follow on from the previous question, I think that modernism or modernity in Cavell's conception of it is a decisive break in history. (Indeed, following Nietzsche's aphorism about breaking history in two, I would say that history itself is a certain breaking into two, dividing the world into history and what comes "before" it). That is to say, before modernism there is tradition, and in tradition there is no (consciousness of) history and therefore in Cavell's sense of the word no art. But after modernism we are in history and the perpetual struggle of art (and thought) to overcome scepticism and keep itself convincing. And precisely too, after modernism, the premodern can only appear as though already struggling with scepticism and the problem of artistic conviction. Modernism at once posits a time before it and does away with this time in its very thinking. So that, if we cannot extract concepts like remarriage from their history, it is also because they make, in their modernity, history itself. But also in a complex way-this is the other task of philosophy-we can try to step back from this history to think that gesture, that inaugural moment, that philosophical and artistic fiat, by which history becomes possible.

CW: A final question. Reviewing, revising, returning, repeating: these categories are really important to Cavell, who often revisits the same material across several articles and books. If you were to rewrite the book now, what (if anything!) would you change? 
RB: Well, of course, according to perfectionism we always fall short and we always must begin again. We write to make up for the mistakes of previous writing. This is just as people speak in Cavell-and, indeed, you get the sense that this is why Cavell is often so long-winded and never-ending-to make up for previous misunderstandings. It is perhaps only in the act of speaking itself - or the actual process of writing a book - that we for a moment "overcome" scepticism. As soon as it is done, as soon as it is set down in writing, we are back in scepticism. But, of course, the two cannot strictly be separated. So I guess after this Cavell book I would like to write a book about Rosalind Krauss and her notion of post-medium. My hypothesis is that her late-9os post-medium writings are not in any way a break with her previous post-modernism and a going back to her original modernism, but that her work-like any significant thinker-is at once absolutely consistent and a perpetual argument with itself. This might be thought as something of an extension of what I have just written on Cavell, but really it's a re-reading of it and indeed a re-reading of it so that it makes more sense to me.

Thank you for your questions, Catherine. Perhaps it's even been something of a high-brow version of Cavell's bantering couples. I'd like to say I was Clark Gable, but I'm probably more like Spencer Tracey!

CW: I'll happily take Katherine Hepburn! Thank you too, Rex, for a terrific conversation. 